\title{
Some Thoughts on Improving Subject Service Level
}

\author{
Xuefei Yu \\ Department of library, Harbin University of Commerce, Harbin, Heilongjiang, China \\ yuxuefei83@163.com
}

Keywords: subject service, university library, subject librarian.

\begin{abstract}
Subject service has gradually become the main direction in development of university library and its core task. In this article we take the library of Harbin University of Commerce as an example, introducing the current development status of subject service and discussing some existing problems. Then we try to put forward some suggestions and hope to promote the development of library subject service.
\end{abstract}

\section{Introduction}

With the development of information technology, the traditional function of library is gradually weakened, so universities libraries in our country are actively seeking new development direction and become reform [1]. Since 1998 Tsinghua University established subject librarian system, many libraries become to follow it [2]. Thus subject service deepen and expand the traditional library services by taking advantage of library resources and provide professional information service in various disciplines or research field to information users. Compared with traditional service, subject service has obvious advantages. On the one hand, it can start from user's point of view to provide targeted, personalized and customized information services. On the other hand, through subject service, users can gradually realize the importance of library in their daily work and scientific research then improve library impression. At the same time, because of ubiquitous knowledge environment and virtual research environment, the network is flooded by a large number of information resources. Academic researchers feel difficult to collect information due to the lack of retrieval knowledge or time. In this case, an organization focus on literature retrieval and information collection is needed urgently, so the background of this era also spawned the emergence and development of subject services.

Under the background of promoting subject service in library, subject librarian system appears [3]. Subject librarians are generally selected from library inside or employ some external professional person to serve and then library designate subject librarian with relevant professional background to perform discipline information service according to the distribution of school discipline. The subject librarian's personal ability is highly required. They should not only have solid professional knowledge but also has the basic knowledge and theory of information retrieval.

Although the establishment of subject service in university libraries has been developing for a long time since 1998, it has not become mature with the increase of time. It can be said that in the early establishment of subject service system, development is extremely slow. Until 2006, followed by the library of China Academy of Sciences proposed a new subject service type [4], the development is gradually accelerated then more and more university libraries and research institutes set up subject librarian and provide subject service. But we found that there are a lot of library did not really carry out subject service although they established subject librarian system and the work of subject librarian do not have a direct relationship to subject service; some libraries reflect that subject librarians with corresponding background are still difficult to integrated into the user's research group so the effect of subject service is not good. Every libraries face different developmental environment and the influence factors of subject services are not the same. This paper takes Harbin University of Commerce as an example, makes a preliminary discussion on current situation, problems and some feasible measures. 


\section{Status and problems of subject service}

\subsection{Subject service status}

The library of Harbin University of Commerce reform and change the traditional service mode and establish subject librarian system promoting subject service in order to use the existing resources to provide more efficient service for the entire school teachers and students. Under the guidance of development policy, library leaders and subject librarians explore and expand the breadth and depth of subject service. Specific measures are as follows:

(1) Subject librarian communication group. The library leaders choose librarians who have professional background in different functional departments and hire them as part-time librarians. Each or two subject librarians are responsible for subject service of college in accordance with their respective professional background. At the same time, these part-time subject librarians indicating the name of college in charge are gathered in one communication group which usually issues a training notice or a variety of news. This approach is conducive for exchange of learning experience, service experience and development thinking.

(2) Subject blog. With the rapid development of computer technology and internet, people can find the information they need on the internet anytime, anywhere. Therefore, library use network space to carry out subject service in the form of subject blog. Subject librarians according to their professional background, collect and collate relevant knowledge on internet and then release on their own academic blog. It is convenient for user to read and also solve the problem of service time limitation. Through the internet we can continuously provide users with information resources. Meanwhile, subject librarian can set style and color of their own blog and can upload photos to explain various complex principles or phenomena in order to enhance user's reading experience.

(3) Subject information navigation. The knowledge of network resources is many but always chaotic, which makes many readers spend a lot of time to find their needed resources thus work efficiency is reduced. In this situation, library establish a subject information navigation platform, which gathers a lot of resources and the same category of resources are integrated into the same subject classification so it is convenient for users to find relevant resources.

(4) Conference announcement. According to the needs of university teachers' academic exchanges, library monthly release information about international and domestic forthcoming academic conference based on our school curriculum and also issue a notice on internal office network so as to be more convenient for readers to carry out academic exchanges. In addition, except for providing regular meeting notice, we can also track corresponding discipline of meeting information according to readers' specific needs, providing targeted personalized service.

(5) Reader training. Like many other university libraries, in order to help our readers to make better use of library resources and improve readers' information retrieval ability, subject librarian carry out reader training work regularly promoting teachers and graduate students to use various retrieval tools.

(6) Citation analysis report. Under the efforts of subject librarian, a citation analysis report was produced, which is based on specific requirements of college analyzing published articles of college teachers in the first author. The citation analysis report gives detailed information about the number of published article each year, article author, published journal, article title and so on. At the same time, subject librarian did annual comparison of documents and calculated $\mathrm{H}$ index and also other indicators. This report is conducive for college leader to master the development of teachers and provide an important reference for college future development.

\subsection{Problems in subject service}

All the measures mentioned above, there are a lot to get a good effect, such as citation analysis report. Many school leaders give positive comments about the work and some other college leaders make requirements to subject librarian of producing such report for their college. But it is undeniable that although some achievements have been made in subject service, there are still some problems, such as followings:

(1) The system part-time subject librarians. This system makes many subject librarians busy with their own work sometimes and no time to take into account the subject services. Once the subject 
service is interrupted, it will not only cause adverse effects to users, but also will bring negative effects on subject librarian's continuous tracking of information. Therefore, although there is subject librarian communication group, in most cases it is only used to send notifications and can not be used for communication.

(2) The visit amount of subject information on internet is low. Although subject librarian has spent a lot of time and energy to make subject blog and library also provides a platform for subject information navigation, the production of subject information is basically collection or initial process of other internet information. In this case, they can not meet the professional information needs of users so the click rate is low.

(3) Readers training efficiency is not high. The reader training pattern of subject service is basically the same as in literature retrieval course and freshman training class. They are all introduce databases using method according to different characteristics and did not vary according to audience. This caused training repeated to a certain extent and at the same time, audience lost interest so the training has become a kind of form and training efficiency is low.

(4) The development of academic services is not enough. The citation analysis report can be regarded as high level subject services in our library harvesting a lot of praise, but there are some problems. In citation analysis report, there is detailed information on teacher's publications, but the analysis of data is not enough, so that the report slightly lack of guiding significance to college development.

\section{Discussion on improvement measures of subject service}

As the direction of future development of modern library, subject service has become the key point of university libraries development. In order to promote the rapid development of subject service, we must first make clear the object of subject service. There is no doubt that subject service is aimed at users and service implementer is subject librarian. Therefore, we should start from user's point of view, but not from the perspective of subject librarian. Here, we do a preliminary discussion on our library service improvement measures:

(1) User classification. Because the object of subject service is user and the type of user in university is more complex. They are freshmen with no basis of retrieval and also professor has academic background. In this case, we should provide different services for different users. Therefore, users can be divided into primary, intermediate and advanced group as well as subject librarian according to professional background or education level. Then subject librarian is allocated to corresponding user group and provides different subject service content. In this way, it not only avoids the waste of human resources, but also set subject librarians a goal or direction.

(2) Mobile terminal. At present, mobile terminal has an irreplaceable advantage although the network and computer is widespread. We can embed academic information services section into WeChat public platform and classify information based on subject then release them regularly or irregularly. Moreover, users on the platform can be classified or gathered into various groups and push related subject information for different user categories. The use of mobile terminals can be faster and provide more convenient communication between subject librarian and user. At the same time, this type of service avoid user visit library repeatedly and is much more convenience.

(3) Subject librarian management system. Because there is no full-time but all part-time librarian at library, which makes establishment of subject librarian management system a must. The management system can not only fully mobilize subject librarian's enthusiasm with reward clause and increase creativity and initiative of subject librarians but can also use punishment mechanism to avoid the slack of subject librarian in information service.

(4) Mobility of subject librarian. Subject service is based on the needs of users, so communication with users is the most direct way to improve subject service effect. Generally, subject librarians are basically in their own office and rarely go to college. In the current situation, users go to library to find information resources are rare. If we wait users to ask us about their requirements, it is difficult to 
carry out academic services. Therefore, subject librarians should go to college all the time and try to understand the information needed of teachers and students then participate the college daily meeting or various trainings.

\section{Conclusion}

The university library subject service work is still a long way to go and inevitably accompanied by painful experiences and mental confusion. It must go through in the process of turning the librarian center into service center. We should have confidence in establishment of subject service although it seems that there are a lot of difficult to cross and it also provides opportunities for self promotion of subject librarians. With the continuous efforts and exploration of subject librarians from generation to generation, we will acquire prosperity of subject service and library development.

\section{Acknowledgments}

This work was financially supported by Doctoral Research Foundation of Harbin University of Commerce.

\section{References}

[1] H. Du, X. Liu, B. C. Yuan, The innovation of subject service based on WeChat public platform in university libraries, Library and Information Service. 59 (2015) 41-45.

[2] J. L. Chu, Q. Q. Kong, G. N. Luan, Research progress of embedded subject service, Library and Information Service. 57 (2013) 11-17.

[3] H. Y. Song, J. Guo, W. Pan, Practical exploration on embedded subject service oriented research teams, Library and Information Service. 56 (2012) 27-30.

[4] J. L. Chu, Difficulties and breakthroughs in subject service in libraries of China, Chinese Journal of Medical Library and Information Science. 21 (2012) 1-4. 